\section{Evaluation of Apple (Malus $\times$ domestica) Genetic Resources in Bosnia and Herzegovina Using Microsatellite Markers}

\author{
Fuad Gasi \\ Faculty of Agriculture and Food Sciences, University of Sarajevo, Zmaja od \\ Bosne 8, 71000 Sarajevo, Bosnia and Herzegovina
}

\section{Silvio Simon}

Department of Plant Breeding, Genetics and Biometrics, Faculty of Agriculture, University of Zagreb, Svetosimunska 25, 10000 Zagreb, Croatia

Naris Pojskic

Laboratory for Molecular Genetics of Natural Resources, Institute for Genetic Engineering and Biotechnology, Zmaja od Bosne 8, Kampus, 71 000, Sarajevo, Bosnia and Herzegovina

\section{Mirsad Kurtovic}

Faculty of Agriculture and Food Sciences, University of Sarajevo, Zmaja od Bosne 8, 71000 Sarajevo, Bosnia and Herzegovina

\section{Ivan Pejic}

Department of Plant Breeding, Genetics and Biometrics, Faculty of Agriculture, University of Zagreb, Svetosimunska 25, 10000 Zagreb, Croatia

\author{
Mekjell Meland ${ }^{1}$ \\ Norwegian Institute for Agricultural and Environmental Research, Bioforsk, \\ Ullensvang, N-5781 Lofthus, Norway
}

\section{Clive Kaiser}

Department of Horticulture, Oregon State University, 418 N. Main Street, Milton-Freewater, OR 97862

\section{Additional index words. local cultivars, genetic differentiation, genetic structure}

Abstract. There is a need for classifying and conserving local apple cultivars from two main regions in Bosnia and Herzegovina $(B \& H)$. Consequently, 71 local apple accessions (31 from Sarajevo and 40 from eastern Bosnia) were evaluated with a set of 10 simple sequence repeats (SSRs). These accessions were compared with 37 reference cultivars (24 traditional B\&H and 13 international cultivars maintained at the ex situ collection Srebrenik) to determine synonyms, homonyms, and possible introgression of foreign genotypes into the local apple germplasm. Using 10 primer pairs of microsatellites, we were able to amplify 135 alleles for the 71 local apple accessions. Detection of more than two different alleles per locus was observed for 34 accessions. Fourteen different homonyms and 12 synonyms were identified among all the apple cultivars analyzed. Analysis of molecular variance (AMOVA) revealed a significant genetic differentiation between most of the groups analyzed but not between accessions from Sarajevo and eastern Bosnia. Bayesian method and admixture analysis of the allele frequency allowed classification of all accessions analyzed and found that they fell into two main groups [reconstructed panmictic populations (RPPs)]. Strong genetic differentiation between these two groups was detected using AMOVA $\left(\mathrm{f}_{\mathrm{CT}}=0.130 ; P<0.001\right)$. Analysis of the genetic structure indicates that overall, approximately half of the local apple cultivars from Sarajevo and eastern Bosnia (52\% and $45 \%$, respectively) grouped in the RPP1 consisting mainly out of international reference cultivars, whereas the other half grouped in the RPP2 with traditional B\&H reference cultivars. Both neighbor joining (NJ) cluster analysis based on Bruvo genetic distance and factorial correspondence analysis (FCA) confirmed the results of the genetic structure analysis. The molecular data show that both apple accessions from Sarajevo and from eastern Bosnia represent an interesting source of diversity, which needs to be conserved.

Traditional apple cultivars in $\mathrm{B} \& \mathrm{H}$ have significantly higher genetic and morphological diversity than modern international cultivars grown in this country (Gasi et al., 2010,
2004), local traditional B\&H apple cultivars may be useful for inclusion in international apple breeding programs and therefore must be conserved. To conserve the aforementioned genetic resource, the main ex situ collection in the country was established in the fruit tree nursery Srebrenik (Spionica, B\&H, lat. $44^{\circ} 45^{\prime} 45^{\prime \prime} \mathrm{N}$, long. $18^{\circ} 29^{\prime} 49^{\prime \prime} \mathrm{E}$ ) in 2000. Aside from local traditional B\&H cultivars, the established collection maintains many international cultivars widely grown in the region, which often serve as reference genotypes in apple germplasm studies. Genetic assessment of 39 accessions, 24 wellknown traditional $\mathrm{B} \& \mathrm{H}$ cultivars and 15 modern international cultivars, maintained at the ex situ collection Srebrenik has recently been performed using molecular markers (Gasi et al., 2010). The molecular analyses revealed a clear differentiation between traditional B\&H cultivars and some of the most widely cultivated modern cultivars in the region, confirming the importance of conserving B\&H apple germplasm. Unfortunately, there are high costs associated with maintaining a large ex situ collection and in a post-conflict country with limited resources, there is an even greater need for increased efficiency and elimination of redundancies by avoiding duplication and mislabeling.

In 2010 and 2011, an effort was made to fill the gaps in the apple collection Srebrenik. During the original collecting missions, completed in 2000, which resulted in establishment of the collection, two geographical areas of Bosnia and Herzegovina were omitted: the capitol Sarajevo with the surrounding area and large parts of eastern Bosnia. The mentioned areas had at that time been significantly depopulated as a result of the war and only in recent years have most of the original inhabitants returned to their homesteads. To ensure that the existing ex situ apple collection contains as much as possible of the diverse $\mathrm{B} \& \mathrm{H}$ apple germplasm, we surveyed the Sarajevo region and parts of eastern Bosnia for local apple cultivars. This was done with the help of local agricultural experts and the traditional knowledge gathered from the farmers living in surveyed parts of the country. The results of the survey indicate a presence of a large number of local cultivars that are grown in the aforementioned regions. However, without knowing the genetic identity of these genotypes, it is impossible to estimate if local cultivars from the surveyed areas can be considered part of traditional $\mathrm{B} \& \mathrm{H}$ apple germplasm or if they are mostly mislabeled international cultivars. Because DNA markers are much more efficient in revealing mislabeled plant accession compared with traditional pomological characterizations (Nybom and Weising, 2010), we chose this approach in our study. SSR molecular markers have shown great promise as tools for managing Malus ex situ germplasm collections as well as for collection and preservation strategies of these genetic resources (Hokansson et al., 1998). Examining ex situ collections with microsatellite markers 
has so far been performed in a number of studies (Garkava-Gustavsson et al., 2008; Gharghani et al., 2009; Guarino et al., 2006; Guilford et al., 1997; Hokanson et al., 2001; Pereira-Lorenzo et al., 2006; Ramos-Cabrer et al., 2007; Urrestarazu et al., 2012; Van Treuren et al., 2010), which has greatly contributed to more efficient management and use of the analyzed collections. Aside from managing established collection, SSR markers have also proved very useful in determining synonyms and genetic relationships of local apple cultivars found on farms (Bassil et al., 2009; Pereira-Lorenzo et al., 2008; Routson et al., 2009).

The objectives of this study therefore were: 1) to compare genetic profiles of local apple cultivars from Sarajevo and eastern Bosnia with a database constructed for previously characterized traditional and international apple cultivars in $\mathrm{B} \& \mathrm{H}$ using a set of 10 SSR markers; and 2) to evaluate the need for conservation of local apple cultivars from Sarajevo and eastern Bosnia.

\section{Materials and Methods}

A total of 71 accessions were sampled from a number of backyards and small farms in Sarajevo and eastern Bosnia (31 from Sarajevo and 40 from eastern Bosnia) (Table 1). The apple accessions, all grafted on generative rootstocks, are maintained in good condition by farmers and their fruits are used for a wide range of purposes (fresh consumption, manufacturing of traditional desserts, and production of apple brandy). Farmers identified each accession as a local, traditional $\mathrm{B} \& \mathrm{H}$ cultivar. In addition, 37 apple accessions (24 well-known traditional B\&H cultivars and 13 international cultivars widely grown in the region) maintained at the ex situ collection Srebrenik and genotyped in a previous study by Gasi et al. (2010) using the same set of SSR markers were included as reference cultivars (Table 2). Traditional B\&H genotypes used as reference cultivars in this study are part of the apple germplasm introduced in Bosnia and Herzegovina during the reign of the Ottoman and later Austrian-Hungary Empire (Bubić, 1952). The mentioned germplasm has extensively been selected by farmers but has yet to be included in plant breeding programs established in the region.

Simple sequence repeat analyses. Tissue samples (leaves) for DNA analyses were collected in the spring of 2011 immediately after bloom from a single tree for each accession

Received for publication 1 Oct. 2012. Accepted for publication 5 Nov. 2012.

This study was funded by the Norwegian government through HERD (Programme for Higher Education, Research and Development) project "Evaluation of fruit genetic resources in BosniaHerzegovina with the aim of sustainable, commercial utilization" ref. no. 332160 UE.

${ }^{1}$ To whom reprint requests should be addressed; e-mail mekjell.meland@bioforsk.no.
Table 1. Seventy one apple accessions ( 31 sampled from farms in Sarajevo and 40 from farms in eastern Bosnia) analyzed in this study using 10 simple sequence repeat markers. ${ }^{z}$

\begin{tabular}{|c|c|c|}
\hline Local name & Accession number & Original place of registration \\
\hline \multicolumn{3}{|l|}{ Sarajevo accessions } \\
\hline Crvenika & SG50 & Škaljića sokak \\
\hline Cvjetača & SG51 & Mošćanica \\
\hline Mađarica & SG52 & Mošćanica \\
\hline Lederka & SG53 & Škaljića sokak \\
\hline Šarenika & SG54 & Širokača \\
\hline Petrovača & SG55 & Obhodža \\
\hline Bobovača & SG56 & Mošćanica \\
\hline Žuta & SG58 & Brusulje \\
\hline Crvenka & SG59 & Hrid-Jarčedoli \\
\hline Zečije uši & SG60 & Hrid-Jarčedoli \\
\hline Cvjetača & $\mathrm{J} 1$ & Širokača \\
\hline Crvena lederica & $\mathrm{J} 3$ & Širokača \\
\hline Siva lederica & $\mathrm{J} 4$ & Širokača \\
\hline Senabija & J5 & Širokača \\
\hline Šarenika kasna & $\mathrm{J} 8$ & Širokača \\
\hline Šupa & $\mathrm{J} 12$ & Obhodža \\
\hline Cvjetača & $\mathrm{J} 13$ & Obhodža \\
\hline Kanada & $\mathrm{J} 15$ & Obhodža \\
\hline Kolarača crvena & $\mathrm{J} 16$ & Obhodža \\
\hline Budimka & $\mathrm{J} 17$ & Obhodža \\
\hline Mirisavka & J18 & Obhodža \\
\hline Petrovača & $\mathrm{J} 21$ & Škaljića sokak \\
\hline Bistrica & SS1 & Škaljića sokak \\
\hline Dobrinjka & SS2 & Škaljića sokak \\
\hline Lederica & SS3 & Baruthana 13 \\
\hline Limun & SS4 & Škaljića sokak \\
\hline Ljepocvjetka & SS5 & Brusulje \\
\hline Sarenika & SS6 & Škaljića sokak \\
\hline Senabija & SS7 & Baruthana 13 \\
\hline Šarenika slatka & SS8 & Širokača \\
\hline Srebrenka & SS9 & Škaljića sokak \\
\hline \multicolumn{3}{|c|}{ Eastern Bosnia accessions } \\
\hline Cvjetača & GC04 & Zupčići \\
\hline Dobrinjka & GD08 & Zupčići \\
\hline Lederica & GL02 & Zupčići \\
\hline Senabija & GS01 & Zupčići \\
\hline Srebrnjača & GS06 & Zupčići \\
\hline Sulija & GS07 & Zupčići \\
\hline Zelenika & GZ03 & Zupčići \\
\hline Zečija glava & GZ05 & Zupčići \\
\hline Ananas & GA11 & Ilovača \\
\hline Amerikanka & GA40 & Zupčići \\
\hline Bistrica & GB10 & Bistrica \\
\hline Butulija & GB14 & Vranići-Zabašča \\
\hline Bedrika & GB16 & Vranići-Zabašča \\
\hline Bihorka & GB27 & Vranići-Kupušnjak \\
\hline Baščenka & GB29 & Kodžaga_polje \\
\hline Babovača & GB30 & Zupčići \\
\hline Bjelka & GB44 & Vranići-Kupušnjak \\
\hline Bijela ruzmarinka & GB45 & Foča \\
\hline Carkonstatin & GC15 & Kostenik-Klupca \\
\hline Crvenka & GC35 & Osanica \\
\hline Dobrinjkina majka & GD38 & Osanica \\
\hline Kanada & GK13 & Zupčići \\
\hline Lorinka & GL31 & Kazagići \\
\hline Limunka & GL36 & Vranići \\
\hline Ljutika & GLJ34 & Kruščica \\
\hline Muslimača & GM18 & Kostenik-Klupca \\
\hline Misirka & GM26 & Ilovača \\
\hline Ovčiji_nos & GO42 & Zupčići \\
\hline Petrovača žuta & GP09 & Zupčići \\
\hline Pazarka & GP17 & Kostenik-Klupca \\
\hline Prisatka & GP20 & Kostenik-Klupca \\
\hline Srčika & GP22 & Ilovača \\
\hline Posavka & GP23 & Mašići \\
\hline Petrovača crvena & GP43 & Zupčići \\
\hline Rebrača & GR19 & Kostenik-Klupca \\
\hline Ranka & GR33 & Vran Potok \\
\hline Šarenika & GS24 & Kostenik-Klupca \\
\hline Samoniklica & GS37 & Vranići \\
\hline Švabska zelenika & GS41 & Zupčići \\
\hline Šimširka & GS46 & Kostenik-Klupca \\
\hline
\end{tabular}

${ }^{\mathrm{z}}$ Collection information includes local name, accession number, and original place of registration. 
Table 2. Twenty-four previously genotyped traditional Bosnia and Herzegovina (B\&H) and 13 international apple accessions maintained in the ex situ collection Srebrenik used as reference cultivars in this study.

\begin{tabular}{|c|c|c|c|c|c|}
\hline & $\begin{array}{l}\text { Traditional B\&H } \\
\text { reference cultivars }\end{array}$ & \multicolumn{2}{|c|}{ Accession no. ${ }^{\mathrm{z}}$} & $\begin{array}{c}\text { International } \\
\text { reference cultivars }\end{array}$ & Accession no. \\
\hline 1 & Paradija & FAS 344 & 1 & Pink Lady & FAS 380 \\
\hline 2 & Šarenika tvrda & FAS 345 & 2 & Topaz & FAS 381 \\
\hline 3 & Sarija & FAS 346 & 3 & Fuji Nagafu & FAS 382 \\
\hline 4 & Bobovec Jon & FAS 347 & 4 & Golden Reinders & FAS 383 \\
\hline 5 & Dobrić & FAS 348 & 5 & Gala Galaxy & FAS 385 \\
\hline 6 & Ruzmarinka & FAS 349 & 6 & Pinova & FAS 386 \\
\hline 7 & Lijepocvjetka & FAS 350 & 7 & Pilot & FAS 387 \\
\hline 8 & Lederka & FAS 351 & 8 & Piros & FAS 389 \\
\hline 9 & Budimka & FAS 352 & 9 & Braeburn & FAS 390 \\
\hline 10 & Senabija & FAS 353 & 10 & Melrose & FAS 391 \\
\hline 11 & Rebrača & FAS 354 & 11 & Elstar & FAS 392 \\
\hline 12 & Samoniklica & FAS 355 & 12 & Granny Smith & FAS 393 \\
\hline 13 & Žuja & FAS 356 & 13 & Jonagold & FAS 394 \\
\hline 14 & Bobovec & FAS 357 & & & \\
\hline 15 & Petrovača bijela & FAS 358 & & & \\
\hline 16 & Tetovka & FAS 359 & & & \\
\hline 17 & Prijedorska zelenika & FAS 360 & & & \\
\hline 18 & Pamuklija & FAS 361 & & & \\
\hline 19 & Bukovija & FAS 362 & & & \\
\hline 20 & Habikuša & FAS 363 & & & \\
\hline 21 & Kanjiška & FAS 364 & & & \\
\hline 22 & Srebrenička & FAS 365 & & & \\
\hline 23 & Funtača & FAS 366 & & & \\
\hline 24 & Đulabija & FAS 367 & & & \\
\hline
\end{tabular}

located in Sarajevo and eastern Bosnia. DNA extraction was performed with a Qiagen DNeasy ${ }^{\circledR}$ Plant Mini Kit (Qiagen, Valencia, CA) according to the protocol included in the kit. Ten primer pairs used for SSR amplifications, previously published by Gianfranceschi et al. (1998) and Liebhard et al. (2002), were chosen in cooperation with a research team from Wageningen University and Research Center and Central gene bank of Netherlands. Polymerase chain reaction (PCR) amplification of SSR sequences was performed in a Veriti TM Thermal Cycler (Applied Biosystems, Foster City, CA) using fluorescentlabeled primers, which enabled the detection of PCR products using an ABI 3130 Genetic Analyzer (Applied Biosystems). All PCR amplifications were performed as described in Gianfranceschi et al. (1998). The PCR product was diluted with ddH20 (1:50), then added to $8.75 \mu \mathrm{HiDi}$ and $0.25 \mu \mathrm{L}$ Genescan 500 LIZ size standard. Data were analyzed using the software package GeneMapper 4.0 (Applied Biosystems).

Biostatistical analyses. SSR profiles obtained by genotyping 71 accessions from Sarajevo and eastern Bosnia were added to the existing microsatellite database constructed in a previous study on apple accessions maintained at the main ex situ apple collection in B\&H. All accessions analyzed were divided into four groups for biostatistical purposes: Sarajevo accessions, eastern Bosnia accessions, international reference cultivars, and traditional $\mathrm{B} \& \mathrm{H}$ reference cultivars.

Population genetics software SPAGeDI 1.2 (Hardy and Vekemans, 2002) was used for calculating allele frequencies, gene diversity (Nei, 1978), and F statistics (Weir and Cockerham, 1984). Analyses of molecular

\section{Results and Discussion}

Simple sequence repeat polymorphism. Of 71 accessions from Sarajevo and eastern Bosnia, 64 showed a unique SSR profile (Table 3 ). When the reference cultivars, genotyped in a previous study (24 wellknown traditional B\&H cultivars and 13 international cultivars widely grown in the region), were included, 14 different homonyms and 12 synonyms were detected among the 108 accessions. Five accessions from eastern Bosnia and three from Sarajevo were already present in the Srebrenik collection under different names. Two accessions registered as local cultivars in the Sarajevo region had in fact the same SSR profile as the international reference cultivar Jonagold, indicating the presence of international genotypes in Sarajevo local apple germplasm. After excluding synonyms and duplicates, 96 different genotypes remained in the new database.

Detection of more than two different alleles per locus was observed for 34 accessions (18 accessions from Sarajevo and 16 from Eastern Bosnia), or $48 \%$ of 71 analyzed local cultivars. Seven of the mentioned accessions had only one locus with third allele, whereas most others had several SSR loci with a third allele. Although flow cytometry is most commonly applied for identifying triploids, because none of the used primer pairs displayed the ability to amplify more than one locus in our study, a presence of a third allele indicates a triploid state. A detected percentage of triploids is considerably higher than that reported for the local Spanish apple cultivars (29\%) (RamosCabrer et al., 2007), as well as compared with the data from the previous molecular study on B\&H apple germplasm (21\%) (Gasi et al., 2010).

Ten primer pairs of microsatellites managed to amplify 135 alleles or an average of 13.5 alleles per locus for the 71 apple accessions sampled from Sarajevo and eastern Bosnia, which represents a $30 \%$ increase compared with the results of the previous study on apple germplasm in Bosnia and Herzegovina (10.4 alleles per loci) (Gasi et al., 2010). Number of detected alleles per locus ranged from seven alleles for $\mathrm{CH} 01 \mathrm{H} 02$ to 22 alleles for $\mathrm{CH} 02 \mathrm{C02a}$ (Table 4). Average number of alleles per locus obtained in this study was also higher than that reported for the Italian, Danish, and Swedish material as well as foreign and local cultivars from northwestern Spain (Garkava-Gustavsson et al., 2008; Guarino et al., 2006; Larsen et al., 2006; Pereira-Lorenzo et al., 2006). Of the two investigated $\mathrm{B} \& \mathrm{H}$ regions, a higher number of alleles was amplified among apple accessions from eastern Bosnia (12.4) compared with Sarajevo accessions (10.5). Lowest numbers were detected for international reference cultivars (6.3).

Analyses of the allele frequency for all the loci revealed SSR alleles specific for each of the four groups of accessions examined. A total of 23 alleles was exclusively present 


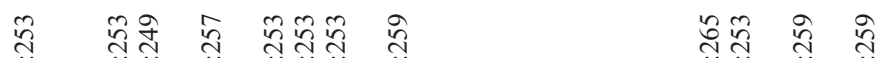

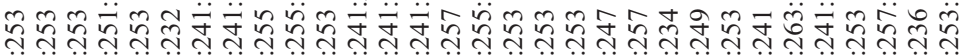

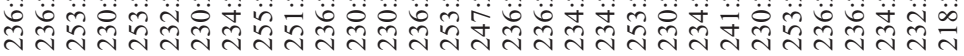

$\stackrel{3}{\exists}$ $\stackrel{9}{=}$

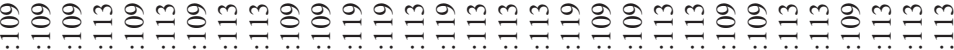

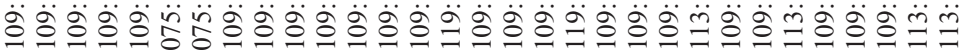

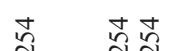

สิ สิ สิ สี

สิ สิ

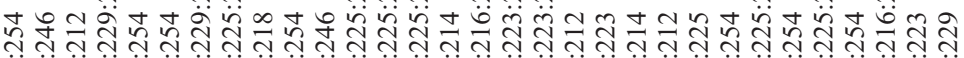

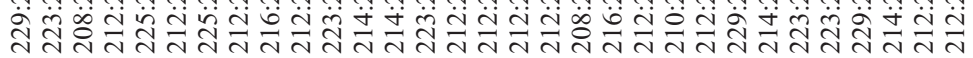

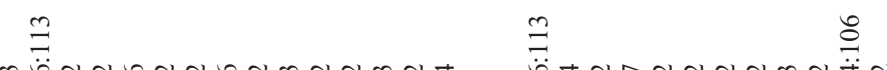

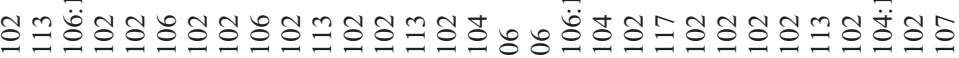

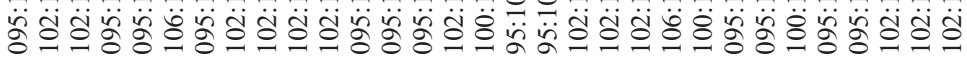

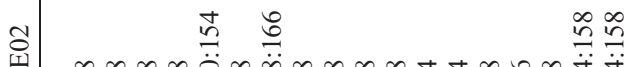

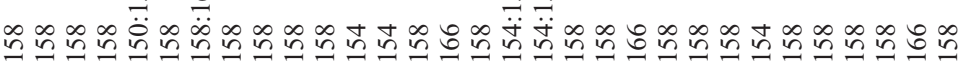

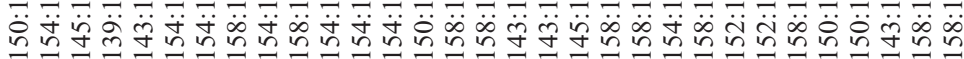

$$
\stackrel{\infty}{\longrightarrow}
$$

$\infty \infty \infty$

$\stackrel{\infty}{\infty} \stackrel{\infty}{\infty} \stackrel{\infty}{\infty}$

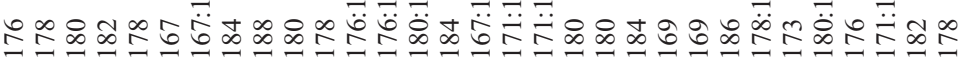

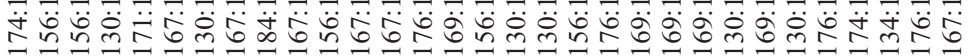

28 वे d)

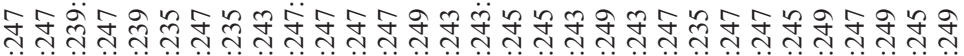

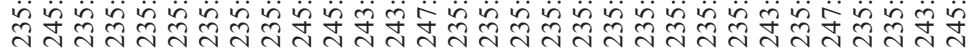
$\stackrel{0}{2}$ $\stackrel{0}{\check{1}}$

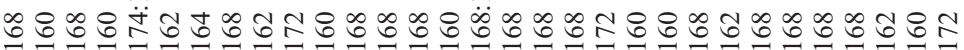



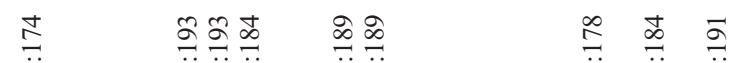

兽

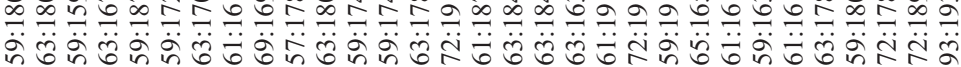

$$
\vartheta \vec{m} \vec{m} \vec{m}
$$$$
\vec{m} \bar{m}
$$

$\frac{9}{7}$

$$
\stackrel{9}{7}
$$

$\vec{m}$ m

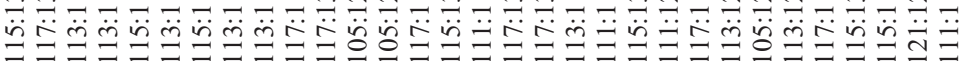

.

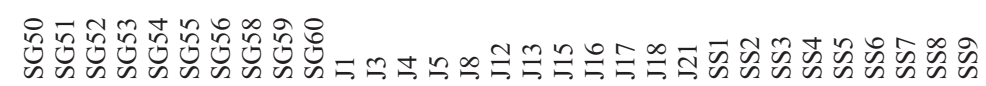<smiles>C1CCCC1</smiles>

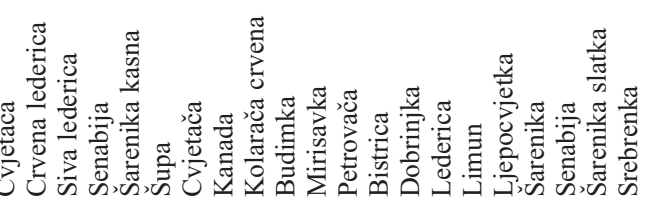

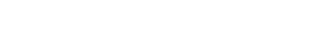

$\overrightarrow{\mathrm{T}}$

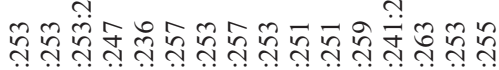

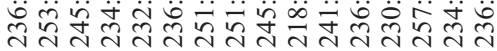
$\bar{I}$

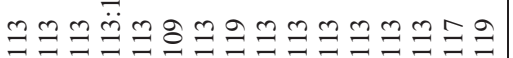

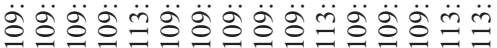

สิ

ปै สิ

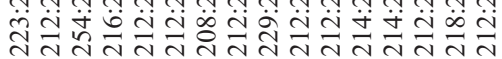

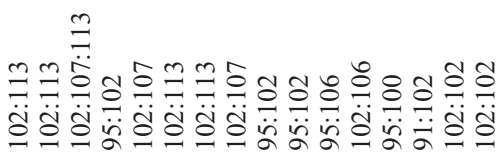

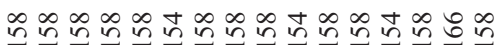

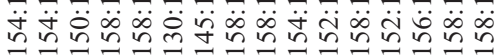

$$
\stackrel{\infty}{\stackrel{\infty}{\infty}}
$$

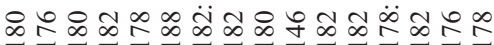

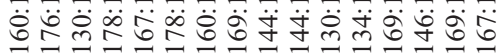

d

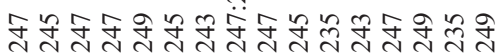

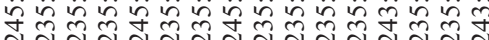

$\stackrel{\infty}{\circ}$ $\stackrel{\infty}{\circ}$

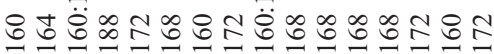

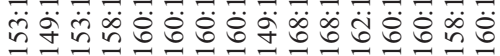

\section{5}

๘ป⿻一㇉凵

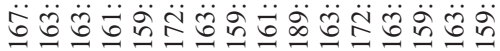

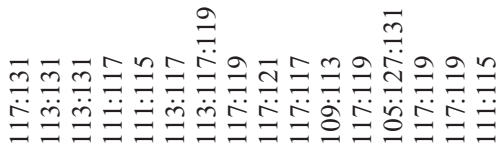

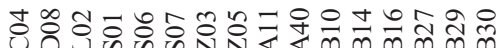

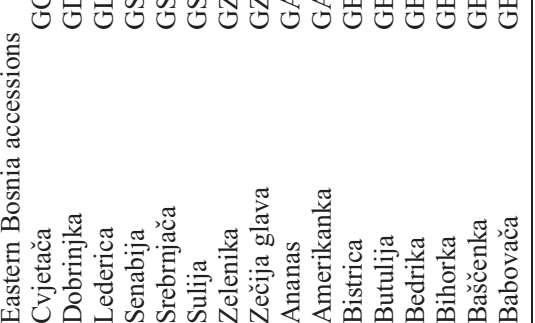




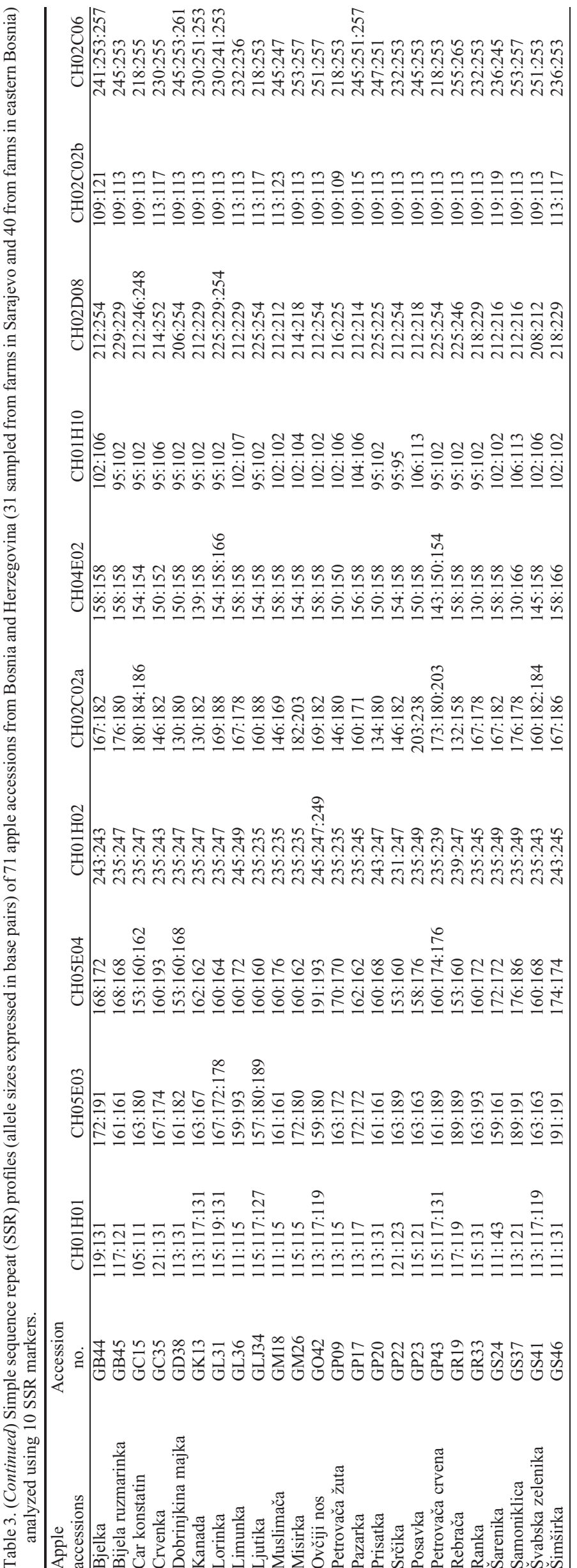

among the accessions from eastern Bosnia, whereas nine alleles were only detected among accessions registered in Sarajevo. Nine different alleles were specific for traditional B\&H reference cultivars, whereas only three alleles were specific for the international reference cultivars.

Gene diversity for individual markers ranged from 0.62 for $\mathrm{CH} 02 \mathrm{CO}$ b to 0.93 for $\mathrm{CH} 02 \mathrm{C02a}$. Average gene diversity estimated in this study was $0.80(0.79$ for Sarajevo and 0.80 for eastern Bosnia accessions), higher than the values published by Hokanson et al. (2001) (0.62), Liebhard et al. (2002) (0.74), and Guarino et al. (2006) (0.73). Gene diversity for 71 accessions from Sarajevo and eastern Bosnia was identical to the one calculated for 109 traditional Spanish cultivars (0.80) (Pereira-Lorenzo et al., 2006) and slightly lower than the values reported by Urrestarazu et al. (2012) (0.82) who analyzed 538 apple cultivars in northeastern Spain. Shannon-Weaver's information index (I) showed diversity to be highest in eastern Bosnia accessions $(I=1.59)$ and the lowest in international reference cultivars $(I=1.11)$. Traditional B\&H reference cultivars and accessions from Sarajevo had similar values for this index $(I=1.38$ and $I=1.39$, respectively). It is important to note that this measure is suitable only when comparing groups of similar size (similar number of analyzed genotypes). Based on the number of amplified alleles, specific alleles, and gene diversity, accessions from eastern Bosnia seem to represent the most genetically diverse group of all four analyzed.

Values for the inbreeding coefficient Fit, calculated for the 71 apple accessions sampled from Sarajevo and eastern Bosnia, ranged from -0.159 for $\mathrm{CH} 01 \mathrm{H} 10$ to 0.182 for $\mathrm{CH} 05 \mathrm{E} 03$ with an average value of -0.047 for all loci (Table 5). The average Fit value calculated for all 108 analyzed accessions (international and traditional $\mathrm{B} \& \mathrm{H}$ reference cultivars included) was also very low $(-0.009)$. Both values were much lower than those previous published for Bosnian, Spanish, and Iranian apple accessions (Gasi et al., 2010; Gharghani et al., 2009; Pereira-Lorenzo et al., 2008). Because high Fit values indicate heterozygosity deficiency, a lower Fit value obtained in this study points to no loss of heterozygosity among the analyzed accessions. Very low values obtained for Fis coefficient $(-0.050$ for Sarajevo and eastern Bosnia accessions and -0.028 for all four groups of accessions) is in concordance with the calculated Fit inbreeding coefficient.

The differentiation between apple accessions from Sarajevo and eastern Bosnia (Fst value) (Weir and Cockerham, 1984) for all 10 loci was very low $(0.002 ; P$ value nonsignificant), possibly indicating a common genetic structure of the genotypes sampled from these two regions. Fst value calculated for all 108 analyzed accessions (international and traditional $\mathrm{B} \& \mathrm{H}$ reference cultivars included) was significant $(0.019 ; P<0.0001)$ but much lower than that reported by the 
Table 4. Allele size range (bp) for all the analyzed apple accessions, number of alleles per locus, and gene diversity (Nei, 1978) based on 10 simple sequence repeat loci for 31 apple accessions from Sarajevo, 40 apple accessions from eastern Bosnia, 71 accession genotyped in this study, 24 traditional Bosnia and Herzegovina $(\mathrm{B} \& \mathrm{H})$, and 13 international reference apple cultivars from ex situ collection Srebrenik.

\begin{tabular}{|c|c|c|c|c|c|c|c|c|c|c|c|}
\hline \multirow[b]{2}{*}{ Locus code } & \multirow[b]{2}{*}{$\begin{array}{c}\text { Size } \\
\text { range (bp) }\end{array}$} & \multicolumn{2}{|c|}{$\begin{array}{l}\text { Sarajevo accessions } \\
\qquad(\mathrm{N}=31)\end{array}$} & \multicolumn{2}{|c|}{$\begin{array}{l}\text { Eastern Bosnia accessions } \\
\qquad(\mathrm{N}=40)\end{array}$} & \multicolumn{2}{|c|}{$\begin{array}{c}\text { Sarajevo and eastern } \\
\text { Bosnia accessions } \\
(\mathrm{N}=71)\end{array}$} & \multicolumn{2}{|c|}{$\begin{array}{c}\text { Traditional } \\
\text { B\&H reference } \\
\text { cultivars }(\mathrm{N}=24)\end{array}$} & \multicolumn{2}{|c|}{$\begin{array}{c}\text { International } \\
\text { reference cultivars } \\
(\mathrm{N}=13)\end{array}$} \\
\hline & & $\begin{array}{l}\text { No. of } \\
\text { alleles }\end{array}$ & $\begin{array}{c}\text { Gene } \\
\text { diversity }\end{array}$ & $\begin{array}{l}\text { No. of } \\
\text { alleles }\end{array}$ & $\begin{array}{c}\text { Gene } \\
\text { diversity }\end{array}$ & $\begin{array}{l}\text { No. of } \\
\text { alleles }\end{array}$ & $\begin{array}{c}\text { Gene } \\
\text { diversity }\end{array}$ & $\begin{array}{l}\text { No. of } \\
\text { alleles }\end{array}$ & $\begin{array}{c}\text { Gene } \\
\text { diversity }\end{array}$ & $\begin{array}{l}\text { No. of } \\
\text { alleles }\end{array}$ & $\begin{array}{c}\text { Gene } \\
\text { diversity }\end{array}$ \\
\hline$\overline{\mathrm{CH} 01 \mathrm{H} 01}$ & $105 / 145$ & 11 & 0.87 & 12 & 0.87 & 14 & 0.87 & 9 & 0.87 & 6 & 0.84 \\
\hline CH05E03 & $153 / 197$ & 17 & 0.92 & 16 & 0.90 & 19 & 0.91 & 12 & 0.86 & 8 & 0.88 \\
\hline CH05E04 & $149 / 193$ & 10 & 0.68 & 15 & 0.84 & 15 & 0.78 & 8 & 0.81 & 7 & 0.76 \\
\hline CH01H02 & $231 / 251$ & 6 & 0.77 & 7 & 0.75 & 7 & 0.76 & 7 & 0.67 & 6 & 0.75 \\
\hline $\mathrm{CH} 02 \mathrm{C} 02 \mathrm{a}$ & $130 / 238$ & 15 & 0.93 & 20 & 0.93 & 22 & 0.93 & 15 & 0.91 & 10 & 0.87 \\
\hline CH04E02 & $130 / 166$ & 8 & 0.67 & 10 & 0.66 & 10 & 0.66 & 8 & 0.47 & 4 & 0.62 \\
\hline CH01H10 & $91 / 119$ & 8 & 0.73 & 8 & 0.70 & 9 & 0.71 & 12 & 0.83 & 6 & 0.79 \\
\hline CH02D08 & $206 / 254$ & 11 & 0.88 & 13 & 0.87 & 14 & 0.87 & 10 & 0.83 & 8 & 0.88 \\
\hline $\mathrm{CH} 02 \mathrm{C} 02 \mathrm{~b}$ & $75 / 123$ & 4 & 0.59 & 7 & 0.64 & 8 & 0.62 & 3 & 0.44 & 2 & 0.47 \\
\hline $\mathrm{CH} 02 \mathrm{C} 06$ & $218 / 265$ & 15 & 0.86 & 16 & 0.89 & 17 & 0.88 & 13 & 0.89 & 6 & 0.78 \\
\hline Mean & & 10.5 & 0.79 & 12.4 & 0.80 & 13.5 & 0.80 & 9.7 & 0.76 & 6.3 & 0.77 \\
\hline
\end{tabular}

Table 5. F-statistics (Weir and Cockerham, 1984; estimated with SPAGeDI 1.2) for 71 apple accessions from Sarajevo and eastern Bosnia and for all 108 analyzed accessions (reference cultivars included) based on 10 simple sequence repeat loci.

\begin{tabular}{|c|c|c|c|c|c|c|c|c|c|c|c|c|}
\hline \multirow[b]{2}{*}{ Locus code } & \multicolumn{6}{|c|}{$\begin{array}{l}\text { Apple accessions from Sarajevo } \\
\text { and eastern Bosnia }(\mathrm{N}=71)\end{array}$} & \multicolumn{6}{|c|}{$\begin{array}{l}\text { Apple accessions from Sarajevo and eastern Bosnia together with } \\
\text { reference cultivars from ex situ collection Srebrenik }(\mathrm{N}=108)\end{array}$} \\
\hline & Fit & $P$ & Fis & $P$ & Fst & $P$ & Fit & $P$ & Fis & $P$ & Fst & $P$ \\
\hline$\overline{\mathrm{CH} 01 \mathrm{H} 01}$ & -0.106 & $<0.0001$ & -0.100 & $<0.0001$ & -0.005 & 0.314 & -0.080 & 0.005 & -0.077 & 0.007 & -0.003 & 0.662 \\
\hline CH05E03 & 0.182 & $<0.0001$ & 0.186 & $<0.0001$ & -0.005 & 0.628 & 0.198 & $<0.0001$ & 0.190 & $<0.0001$ & 0.010 & 0.077 \\
\hline CH05E04 & -0.035 & 0.497 & -0.050 & 0.346 & 0.015 & 0.061 & 0.014 & 0.730 & -0.010 & 0.829 & 0.023 & $<0.0001$ \\
\hline $\mathrm{CH} 01 \mathrm{H} 02$ & -0.145 & 0.003 & -0.135 & 0.013 & -0.009 & 0.135 & -0.078 & 0.095 & -0.108 & 0.030 & 0.027 & 0.009 \\
\hline $\mathrm{CH} 02 \mathrm{C} 02 \mathrm{a}$ & -0.019 & 0.535 & -0.030 & 0.272 & 0.011 & 0.051 & -0.010 & 0.656 & -0.031 & 0.216 & 0.021 & $<0.0001$ \\
\hline CH04E02 & -0.009 & 0.934 & -0.002 & 0.999 & -0.007 & 0.482 & 0.012 & 0.806 & 0.002 & 0.890 & 0.010 & 0.209 \\
\hline $\mathrm{CH} 01 \mathrm{H} 10$ & -0.159 & 0.007 & -0.151 & 0.008 & -0.008 & 0.241 & -0.119 & 0.003 & -0.131 & $<0.0001$ & 0.011 & 0.095 \\
\hline CH02D08 & -0.080 & 0.037 & -0.078 & 0.026 & -0.002 & 0.886 & -0.066 & 0.035 & -0.072 & 0.015 & 0.006 & 0.227 \\
\hline $\mathrm{CH} 02 \mathrm{C} 02 \mathrm{~b}$ & -0.081 & 0.343 & -0.113 & 0.159 & 0.029 & 0.061 & 0.075 & 0.305 & 0.013 & 0.819 & 0.063 & 0.003 \\
\hline $\mathrm{CH} 02 \mathrm{C} 06$ & -0.066 & 0.025 & -0.073 & 0.032 & 0.006 & 0.203 & -0.038 & 0.153 & -0.068 & 0.009 & 0.029 & $<0.0001$ \\
\hline ALL LOCI & -0.047 & $<0.0001$ & -0.050 & $<0.0001$ & 0.002 & 0.391 & -0.009 & 0.459 & -0.028 & 0.025 & 0.019 & $<0.0001$ \\
\hline
\end{tabular}

previous studies, which examined differentiation between traditional and international apple cultivars in Bosnia and in Spain (Gasi et al., 2010; Pereira-Lorenzo et al., 2006, 2008). Further examination of genetic differences among the four groups of apple accessions was performed using AMOVA. AMOVA calculated for all 108 analyzed accessions indicated that most of the variance was retained within the groups of accession $(99 \%)$, whereas $1 \%$ of the total diversity was attributed to the differences among the analyzed groups of accessions (Table 6). The largest percentage of variance between the groups was detected among apple accessions from Sarajevo and international reference cultivars $\left(\mathrm{f}_{\mathrm{CT}}=0.051 ; P<0.01\right)$ as well as among apple accessions from eastern Bosnia and international reference cultivars $\left(\mathrm{f}_{\mathrm{CT}}=\right.$ 0.058; $P<0.01)$.

The smallest percentage of variance between the groups was detected among apple accessions from Sarajevo and eastern Bosnia ( $f_{\mathrm{CT}}=0.001 ; P$ value nonsignificant $)$, which is in concordance with the low Fst values calculated for these groups. Nonsignificant $\mathrm{f}_{\mathrm{CT}}$ was also calculated among apple accessions from eastern Bosnia and traditional $\mathrm{B} \& \mathrm{H}$ reference cultivars, indicating that both of the groups, at least in part, belong to the same germplasm. Although the percentage of variance among apple accessions from Sarajevo and traditional $\mathrm{B} \& \mathrm{H}$ reference cultivars
Table 6. Analysis of molecular variance (AMOVA) based on the 10 simple sequence repeat loci of 71 apple accessions corresponding to two areas in Bosnia and Herzegovina (B\&H) (Sarajevo and eastern Bosnia) as well as 24 traditional $\mathrm{B} \& \mathrm{H}$ and 13 international reference apple cultivars from the ex situ collection Srebrenik and to the two reconstructed populations (RPPs) defined by Structure (Pritchard et al., 2000).

\begin{tabular}{|c|c|c|c|c|c|}
\hline $\begin{array}{l}\text { Source of } \\
\text { variation }\end{array}$ & df & $\begin{array}{c}\text { Variance } \\
\text { components }\end{array}$ & $\begin{array}{c}\text { Total } \\
\text { variance }(\%)\end{array}$ & $f_{C T}$ & $P$ \\
\hline \multicolumn{6}{|c|}{ All 108 analyzed accessions (reference cultivars included) } \\
\hline Among groups & 104 & 78.95 & 99.0 & \multirow[t]{3}{*}{0.010} & \multirow[t]{3}{*}{$<0.01$} \\
\hline Within groups & 3 & 0.79 & 1.0 & & \\
\hline Total & 107 & 79.74 & & & \\
\hline \multicolumn{6}{|c|}{ Apple accessions from Sarajevo and eastern Bosnia } \\
\hline Among groups & 69 & 80.61 & 99.9 & \multirow[t]{3}{*}{0.001} & \multirow[t]{3}{*}{0.3720} \\
\hline Within groups & 1 & 0.10 & 0.1 & & \\
\hline Total & 70 & 80.71 & & & \\
\hline \multicolumn{6}{|c|}{ Apple accessions from Sarajevo and international reference cultivars } \\
\hline Among groups & 42 & 75.80 & 94.9 & \multirow[t]{3}{*}{0.051} & \multirow[t]{3}{*}{$<0.01$} \\
\hline Within groups & 1 & 4.10 & 5.1 & & \\
\hline Total & 43 & 79.91 & & & \\
\hline \multicolumn{6}{|c|}{ Apple accessions from Sarajevo and traditional B\&H reference cultivars } \\
\hline Among groups & 53 & 78.04 & 97.1 & \multirow[t]{3}{*}{0.029} & \multirow[t]{3}{*}{$<0.05$} \\
\hline Within groups & 1 & 2.31 & 2.9 & & \\
\hline Total & 54 & 80.35 & & & \\
\hline \multicolumn{6}{|c|}{ Apple accessions from eastern Bosnia and international reference cultivars } \\
\hline Among groups & 51 & 79.96 & 94.2 & \multirow[t]{3}{*}{0.058} & \multirow[t]{3}{*}{$<0.01$} \\
\hline Within groups & 1 & 4.89 & 5.8 & & \\
\hline Total & 52 & 84.85 & & & \\
\hline \multicolumn{6}{|c|}{ Apple accessions from eastern Bosnia and traditional B\&H reference cultivars } \\
\hline Among groups & 62 & 81.24 & 98.8 & \multirow[t]{3}{*}{0.012} & \multirow[t]{3}{*}{0.0940} \\
\hline Within groups & 1 & 0.96 & 1.2 & & \\
\hline Total & 63 & 82.20 & & & \\
\hline \multicolumn{6}{|l|}{ RPPs } \\
\hline Among RPPs & 104 & 74.98 & 87.0 & \multirow[t]{3}{*}{0.130} & \multirow[t]{3}{*}{$<0.001$} \\
\hline Within RPPs & 1 & 11.17 & 13.0 & & \\
\hline Total & 105 & 86.15 & & & \\
\hline
\end{tabular}




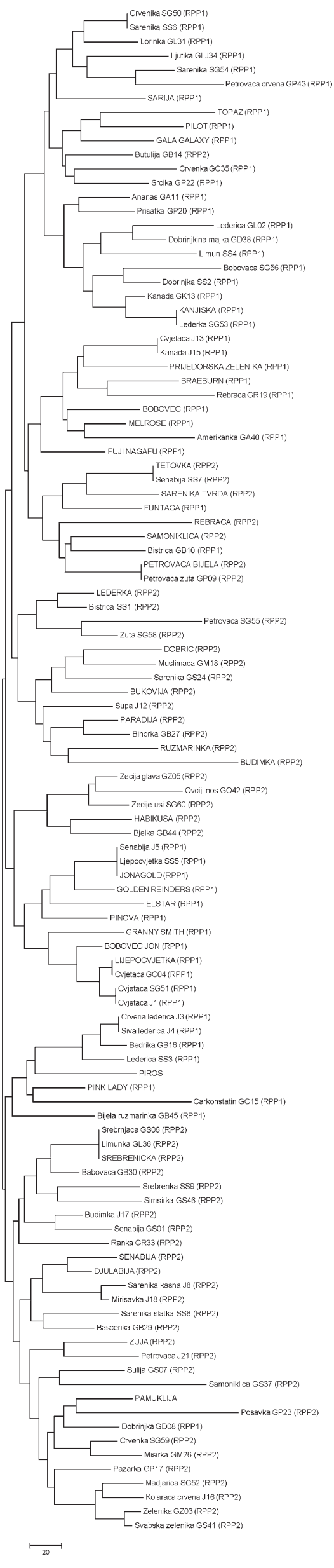

was low $(2.9 \%)$, it was significant $(P<0.05)$, indicating that a significant part of Sarajevo accessions belongs to the international apple germplasm.

Genetic relationships. Bayesian analyses, which were done within Structure, revealed that almost all of the international reference cultivars (92\%) grouped in RPP1, whereas most traditional $\mathrm{B} \& \mathrm{H}$ reference cultivars (71\%) were in RPP2. Local apple cultivars from Sarajevo and eastern Bosnia grouped in both RPPs. The first RPP included 53 genotypes, all of them with $q I$ greater than $80 \%$. Of those, 12 were international reference cultivars, seven traditional $\mathrm{B} \& \mathrm{H}$ reference cultivars, 16 apple accessions from Sarajevo, and 18 accessions from eastern Bosnia. The second RPP included 55 genotypes, 53 of them with $q I$ greater than $80 \%$. Of those, 16 were traditional $\mathrm{B} \& \mathrm{H}$ reference cultivars, 15 apple accessions from Sarajevo, and 22 accessions from eastern Bosnia. Overall, approximately half of the local apple cultivars from Sarajevo and eastern Bosnia (52\% and $45 \%$, respectively) grouped in the RPP consisting mainly out of international cultivars, whereas the other half grouped in the RPP with traditional B\&H reference cultivars. Structure analysis therefore confirmed the conclusion based on the AMOVA results, that the local accessions analyzed in this study represent a mixture of traditional $\mathrm{B} \& \mathrm{H}$ and international germplasm. The variance among RPPs $(13 \% ; P<0.001)$ (Table 6) was significant, although slightly lower than reported by Pereira-Lorenzo et al. (2008) (14.41\%) for RPPs constructed with Spanish and international cultivars but higher than the values obtained by Gasi et al. (2010) (9.2\%) in a previous study on apple germplasm in $\mathrm{B} \& \mathrm{H}$.

NJ cluster analysis was used to group all 108 examined accessions (Fig. 1). The tree was constructed based on a genetic distance model, which takes into consideration mutation characteristics of microsatellites and allows genotypes with different ploidy level to be included in analyses (Bruvo et al., 2004). Although the separation of most of the traditional $\mathrm{B} \& \mathrm{H}$ and international reference cultivars was evident, accessions from Sarajevo and eastern Bosnia were dispersed throughout the entire dendrogram. A large number of the mentioned accessions formed clusters exclusively with traditional $\mathrm{B} \& \mathrm{H}$ reference cultivars, whereas a slightly smaller number grouped very tightly with international reference cultivars indicating introgression of foreign genotypes into the local germplasm and/or presence of mislabeled

Fig. 1. Neighbor joining cluster analysis based on polymorphisms of 10 simple sequence repeat loci in 71 local apple cultivars and 37 reference apple cultivars (written in capital letters) using Bruvo genetic distance (Bruvo et al., 2004). In brackets are the reconstructed populations (RPP1 or RPP2) to which each cultivar is assigned with probability of membership $q I$ greater than $80 \%$. international cultivars. In Figure 1, all cultivars with $q I$ over the minimum threshold of $80 \%$ were assigned to one of the two RPPs. It is interesting to note that although NJ cluster analysis based on Bruvo genetic distance represents a different biostatistical approach than the Bayesian model-based cluster procedure in Structure, the results of both analyses largely concurred. Namely, only three accessions from the RPP1 clustered tightly with genotypes from RPP2, whereas only one accession from RRP2 grouped in a cluster containing RPP1 accessions (Fig. 1).

To get a clearer picture of the relationships between the analyzed groups of accessions, a multivariate approach based on FCA analysis was used. The three-dimensional plot (Fig. 2) revealed a clear differentiation between the traditional $\mathrm{B} \& \mathrm{H}$ and international reference cultivars, whereas the groups of accessions from Sarajevo and eastern Bosnia overlapped. Because the genetic differentiation between these groups is negligible (nonsignificant values for Fst and $P$ in AMOVA), this was completely expected. Apple accessions from both Sarajevo and eastern Bosnia generally clustered closer to traditional than to the international reference cultivars, whereas some overlapping between eastern Bosnia and traditional B\&H reference group was noted. Both of these observations are in concordance with the results of ANOVA (Table 6). Factorial correspondence analysis was also done for the two RPPs and it revealed a strong genetic differentiation between RPP1 and RPP2 (Fig. 3), which is in concordance with the results of AMOVA.

\section{Conclusions}

Molecular data indicated that both groups of apple accessions analyzed (from Sarajevo and from eastern Bosnia) represent an interesting source of diversity, which needs to be conserved. Although introgression of international reference cultivars in local apple germplasm was detected, both groups contain a large number of diverse traditional $\mathrm{B} \& \mathrm{H}$ apple cultivars, which have so far not been preserved, and inclusion of all this material in the ex situ collection is imperative. In this process, priority should be given to all the local apple accessions from Sarajevo and eastern Bosnia, which grouped in the RPP2. Accessions maintained in the ex situ collection can then be investigated for advantageous agronomic traits.

\section{Literature Cited}

Bassil, N., K. Hummer, J. Postman, G. Fazio, A Baldo, I. Armas, and R. Williams. 2009. Nomenclature and genetic relationships of apples and pears from Terceira Island. Genet. Resources Crop Evol. 56:339-352.

Belkhir, K., P. Borsa, L. Chikhi, N. Raufast, and F. Bonhomme. 2001. GENETIX 4.02, logiciel sous Windows TM pour la génétique des populations. Laboratoire Génome, Populations, Interactions, CNRS UMR 5000, Université de Montpellier II, Montpellier, France. 


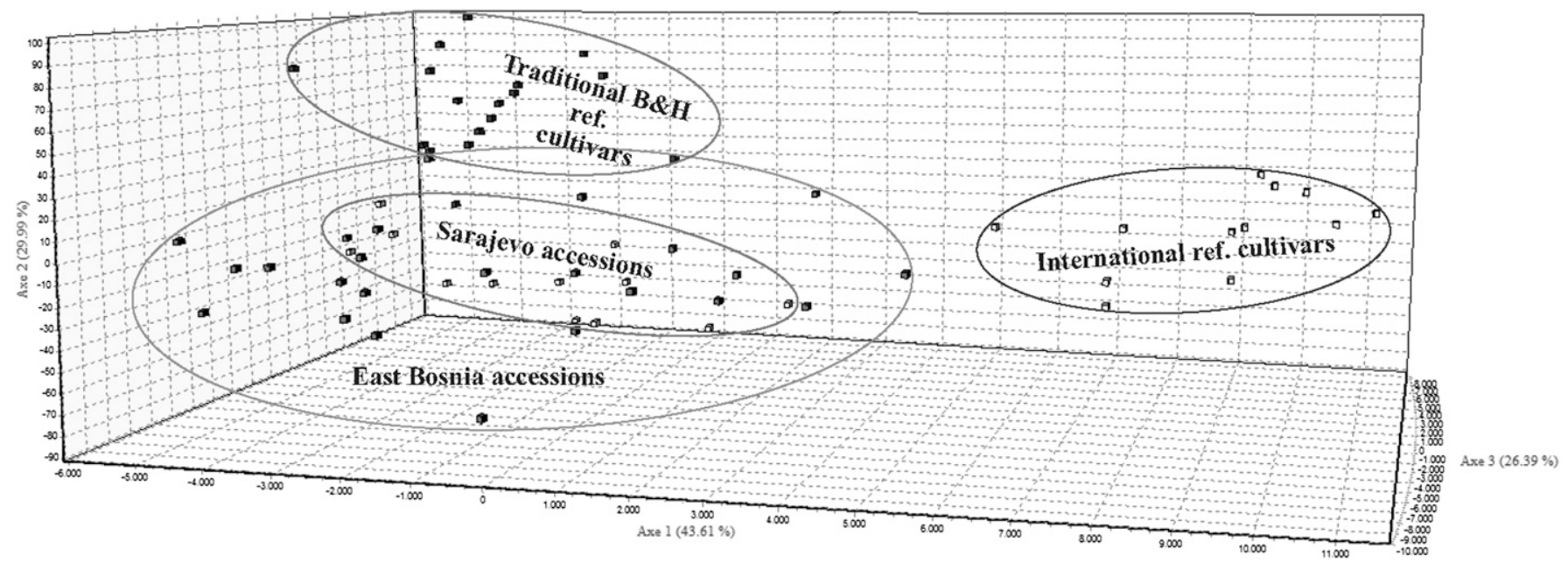

Fig. 2. Multivariate analysis (factorial correspondence analysis) of simple sequence repeat data for 37 apple accessions from two areas in Bosnia and Herzegovina $(\mathrm{B} \& \mathrm{H})$ (13 from Sarajevo and 24 from eastern Bosnia) as well as 19 traditional B\&H and 12 international reference apple cultivars from ex situ collection Srebrenik (diploids analyzed only).

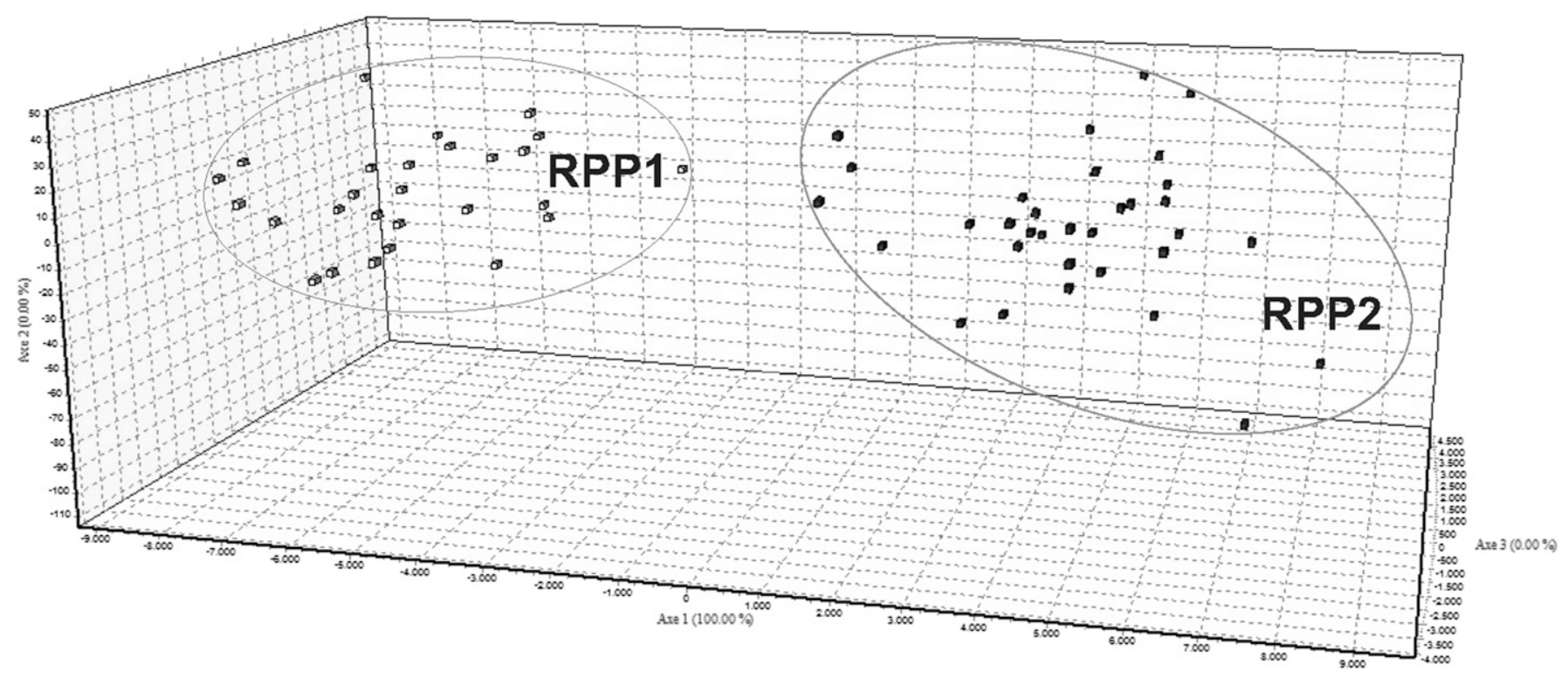

Fig. 3. Multivariate analysis (factorial correspondence analysis) of simple sequence repeat data for reconstructed populations (RPPs) calculated using Structure (Pritchard et al., 2000) (only diploid genotypes with $q I$ greater than $80 \%$ ). Ninety-two percent of the international reference cultivars grouped in RPP1, whereas $71 \%$ of traditional Bosnia and Herzegovina $(B \& H)$ reference cultivars were in RPP2. Local apple cultivars from Sarajevo and eastern Bosnia grouped in both RPPs.

Breton, C., C. Pinatel, F. Médail, F. Bonhomme, and A. Bervillé. 2008. Comparison between classical and Bayesian methods to investigate the history of olive cultivars using SSRpolymorphisms. Plant Sci. 175:524-532.

Bruvo, R., K.N. Michiels, T.G. D'Souza, and H. Schulenburg. 2004. A simple method for the calculation of microsatellite genotype distances of ploidy level. Mol. Ecol. 13:2101-2106.

Bubić, Š. 1952. Specijalno voćarstvo. Veselin Masleša, Sarajevo.

Di Rienzo, A., A.C. Peterson, J.C. Garza, A.M Valdes, M. Slatkin, and N.B. Freimer. 1994. Mutational processes of simple-sequence repeat loci in human populations. Proc. Natl. Acad. Sci. USA 91:3166-3170.

Exoffier, L., P.E. Smouse, and J.M. Quattro. 1992. Analysis of molecular variance inferred from metric distances among DNA haplotypes: Application to human mitochondrial DNA restriction data. Genetics 131:479-491.
Garkava-Gustavsson, L., K. Kolodinska-Brantestam, J. Šehić, and H. Nybom. 2008. Molecular characterization of indigenous Swedish apple cultivars based on SSR and S-allele analysis. Hereditas 145:99-112.

Gasi, F., S. Simon, N. Pojskic, M. Kurtovic, and I. Pejic. 2010. Genetic assessment of apple germplasm in Bosnia and Herzegovina using microsatellite and morphologic markers. Sci. Hort. 126:164-171.

Gasi, F., S. Šimon, N. Pojskić, M. Kurtović, and I. Pejić. 2011. Analysis of morphological variability in Bosnia and Herzegovina's autochthonous apple germplasm. J. Food Agr. Environ. 9:444-448.

Gharghani, A., Z. Zamani, A. Talaie, C.N. Oraguzie, R. Fatahi, H. Hajnajari, C. Wiedow, and S.E. Gardiner. 2009. Genetic identity and relationships of Iranian apple (Malus $\times$ domestica Borkh.) cultivars and landraces, wild Malus species and representative old apple cultivars based on simple sequence repeat (SSR) markers analysis. Genet. Resources Crop Evol. 56:829842.

Gianfranceschi, L., N. Seglia, R. Tarchini, M. Komjanc, and C. Gessler. 1998. Simple sequence repeats for the genetic analyses of apple. Theor. Appl. Genet. 96:1069-1079.

Guarino, C., S. Santoro, L. De Simone, O. Lain, G. Cipriani, and R. Testolin. 2006. Genetic diversity in a collection of ancient cultivars of apple (Malus $\times$ domestica Borkh.) as revealed by SSR-based fingerprinting. J. Hort. Sci. Biotechnol. 81:39-44.

Guilford, P., S. Prakash, J.M. Zhu, E. Rikkerink, S. Gardiner, H. Bassett, and R. Forster. 1997. Microsatellites in Malus $\times$ domestica (apple): Abundance, polymorphism and cultivar identification. Theor. Appl. Genet. 94:249-254.

Hardy, O.J. and X. Vekemans. 2002. SPAGeDi: A versatile computer program to analyze spatial genetic structure at the individual or 
population levels. Mol. Ecol. Notes 2:618620.

Hokanson, S.C., W.F. Lamboy, A.K. Szewc-McFadden, and J.R. McFerson. 2001. Microsatellite (SSR) variation in a collection of Malus (apple) species and hybrids. Euphytica 118:281-294.

Hokansson, S.C., A.K. Szewc-McFadden, W.F. Lamboy, and J.R. McFerson. 1998. Microsatellite (SSR) markers reveal genetic identities, genetic diversity and relationship in a Malus $\times$ domestica Borkh. core subset collection. Theor. Appl. Genet. 97:671-683.

Kellerhals, M., L. Bertschinger, and S. Gessler. 2004. Use of genetic resources in apple breeding and for sustainable fruit production. Journal of Fruit and Ornamental Plant Research 12:53-62.

Larsen, A.S., C.B. Asmussen, E. Coart, D.C. Olrik, and E.D. Kjær. 2006. Hybridization and genetic variation in Danish populations of European crab apple (Malus sylvestris). Tree Genet. Genomes 2:86-97.

Liebhard, R., L. Gianfranceschi, B. Koller, C.D. Ryder, R. Tarchini, E. Van De Weg, and C. Gessler. 2002. Development and characterization of 140 new microsatellite in apple (Malus $\times$ domestica Borkh.). Mol. Breed. 10:217-241.

Meirmans, P. and P. Van Tienderen. 2004. Genotype and Genodive: Two programs for the analysis of genetic diversity of asexual organisms. Mol. Ecol. Notes 4:792-794.
Nei, M. 1978. Estimation of average heterozygosity and genetic distance from a small number of individuals. Genetics 89:583-590.

Nybom, H. and K. Weising. 2010. DNA-based identification of clonally propagated cultivars, p. 221-295. In: Janick, J. (ed.). Plant breeding reviews. Vol. 34.

Ohta, T. and M. Kimura. 1973. A model of mutation appropriate to estimate the number of electrophoretically detectable alleles in a finite population. Genet. Res. 22:201-204.

Pereira-Lorenzo, S., A.M. Ramos-Cabrer, and M.B. Diaz-Hernandez. 2006. Evaluation of genetic identity and variation of local apple cultivars (Malus $\times$ domestica Borkh.) from Spain using microsatellite markers. Genet. Resources Crop Evol. 54:405-429.

Pereira-Lorenzo, S., A.M. Ramos-Cabrer, A.J. Gonzalez-Diaz, and M.B. Diaz-Hernandez. 2008. Genetic assessment of local apple cultivars from La Palma Spain, using simple sequence repeats (SSRs). Sci. Hort. 117:160166.

Pritchard, J.K., M. Stephens, and P. Donnelly. 2000. Inference of population structure using multilocus genotype data. Genetics 155:945959.

Ramos-Cabrer, A.M., M.B. Diaz-Hernandez, and S. Pereira-Lorenzo. 2007. Use of microsatellites in the management of genetic resources of
Spanish apple cultivars. J. Hort. Sci. Biotechnol. 82:257-265.

Routson, K.J., A.A. Reilley, A.D. Henk, and G.M. Volk. 2009. Identification of historic apple trees in the southwestern United States and implications for conservation. HortScience 44: 589-594.

Tamura, K., D. Peterson, N. Peterson, G. Stecher, M. Nei, and S. Kumar. 2011. MEGA5: Molecular evolutionary genetics analysis using maximum likelihood, evolutionary distance, and maximum parsimony methods. Mol. Biol. Evol. 28:2731-2739.

Urrestarazu, J., C. Miranda, L.G. Santesteban, and J.B. Royo. 2012. Genetic diversity and structure of local apple cultivars from northeastern Spain assessed by microsatellite markers. Tree Genet. Genomes. DOI: 10.1007/s11295-0120502-y.

Weir, B.S. and C.C. Cockerham. 1984. Estimating F-statistics for the analysis of population structure. Evolution 38:1358-1370.

Van Treuren, R., H. Kemp, G. Ernsting, B. Jongejans, H. Houtman, and L. Visser. 2010. Microsatellite genotyping of apple (Malus $\times$ domestica Borkh.) genetic resources in the Netherlands: Application in collection management and variety identification. Genet. Resources Crop Evol. 57:853865 . 